\title{
PERLINDUNGAN SAKSI DALAM BEBERAPA TINDAK PIDANA DAN PENGADILAN HAK ASASI MANUSIA
}

\author{
Suhaimi \\ Ilmu Hukum, Fakultas Hukum, Univeritas Syiah Kuala \\ Jln. Putroe Phang No.1, Darussalam, Banda Aceh, 23111 \\ pak_emy@unsyiah.ac.id
}

\begin{abstract}
Article 184 of the Criminal Procedure Code puts witness statements first among other evidence. Witnesses in giving their statements, both at the level of investigation, prosecution and court proceedings, sometimes experience pressure, harassment, threats, terror and even violence perpetrated by certain parties. That is why witnesses need to obtain legal protection, namely as regulated in Law No.13 of 2006 concerning Protection of Witnesses and Victims as amended by Law No. 31 of 2014 concerning Amendments to Law No. 13 of 2006 concerning Protection of Witnesses and Victims. Several criminal acts that regulate the issue of witness protection include the crime of narcotics, the eradication of corruption, the crime of terrorism and the human rights court. Legal protection for witnesses, namely in the form of protection for the witness's personal security from physical and mental threats, so that the confidentiality and identity of the witnesses should be maintained. Witness protection is intended to be able to protect witnesses from interference, threats, terror and violence against witnesses. This will be the basis for legal certainty, law enforcement, justice and the creation of a feeling of security for witnesses.
\end{abstract}

Keymords. Witnesses, Crime and Human Rights Court.

Intisari, Pasal 184 KUHAP meletakkan keterangan saksi pada urutan pertama diantara alatalat bukti lainnya. Saksi dalam memberikan keterangannya, baik pada tingkat penyidikan, penuntutan maupun di sidang pengadilan, kadang-kadang mengalami tekanan, gangguan, ancaman, teror dan bahkan kekerasan yang dilakukan oleh pihak-pihak tertentu. Itulah sebabnya maka saksi perlu mendapatkan perlindungan hukum, yaitu sebagaimana diatur dalam Undang-Undang No.13 Tahun 2006 tentang Perlindungan Saksi dan Korban yang telah diubah dengan Undang-Undang No.31 Tahun 2014 tentang Perubahan Atas UndangUndang No.13 Tahun 2006 tentang Perlindungan Saksi dan Korban. Beberapa tindak pidana yang mengatur masalah perlindungan saksi antara lain tindak pidana narkotika, pemberantasan tindak pidana korupsi, tindak pidana terorisme dan pengadilan Hak Asasi Manusia (HAM). Perlindungan hukum terhadap saksi, yaitu berupa perlindungan atas keamanan pribadi saksi dari ancaman fisik maupun mental, sehingga perlu dijaga kerahasiaan dan identitas saksi. Perlindungan saksi tersebut dimaksudkan untuk dapat melindungi saksi dari adanya gangguan, ancaman, teror dan kekerasan terhadap saksi. Hal tersebut akan menjadi dasar bagi kepastian hukum, penegakan hukum, keadilan dan dapat menciptakan rasa aman bagi saksi.

Kała Kund: Saksi, Tindak Pidana dan Pengadilan Hak Asasi Manusia.

\section{Pendahuluan}

Kesaksian atau alat bukti keterangan-saksi merupakan alat bukti yang palimg penting dalam proses peradilan pidana. Mengingat betapa pentingnya keterangan saksi, maka Undang-Undang No.8 Tahun 1981 tentang Hukum Acara Pidana yang 
lazim disebut dengan KUHAP, menempatkan keterangan saksi pada posisi paling atas di antara alat-alat bukti lainnya. Hal ini sebagaimana dirumuskan dalam Pasal 184 ayat (1) KUHAP mengenai alat-alat-bukti-yang-sah adalah:
a. Keterangan-saksi.
b. Keterangan-ahli.
c. Surat.
d. Petunjuk.
e. Keterangan terdakwa.

Menurut M. Yahya Harahap, "alat bukti yang paling utama dalam perkara pidana adalah alat bukti berupa keterangan-saksi". " Hal ini disebabkan bahwa "hampir tidak ada perkara pidana yang luput dari pembuktian alat bukti berupa keterangan saksi. Hampir semua pembuktian perkara pidana selalu bersandar pada pemeriksaan saksi".2

Jika dilihat pada ketentuan Pasal 184 KUHAP, keterangan saksi ditempatkan dalam deretan pertama dari sejumlah alat bukti dalam KUHAP, dimana saksi adalah orang yang mendengar, melihat, dan mengalami sendiri tindak pidana yang bersangkutan. Hal ini sesuai dengan bunyi Pasal 1 angka 26 KUHAP yang menyatakan bahwa "Saksi adalah orang yang dapat memberikan keterangan guna kepentingan penyidikan, penuntutan, dan peradilan tentang suatu perkara pidana yang ia dengar sendiri, ia lihat sendiri dan ia alami sendiri”.

Oleh karena keterangan saksi merupakan keterangan yang diperoleh dari orang yang mendengar sendiri, melihat sendiri dan yang mengalami sendiri tentang suatu tindak pidana, maka terbukti atau tidaknya terdakwa di depan sidang pengadilan mengenai tindak pidana yang didakwakan kepadanya sangat tergantung pada isi keterangan saksi, di samping alat-alat bukti lainnya. Dalam arti bahwa apabila saksi tersebut dalam memberikan keterangan mengenai apa yang dilihat, didengar dan dialaminya tersebut sesuai dengan apa yang didakwakan kepada terdakwa, maka ditambah dengan satu alat bukti lainnya terdakwa akan dinyatakan bersalah dan dijatuhi hukuman. Dengan demikian dapat dikatakan bahwa keterangan saksi turut menentukan masa depan terdakwa, apakah terdakwa akan dihukum atau dibebaskan.

Mengingat betapa besarnya peranan saksi dalam suatu perkara pidana, maka tidaklah berlebihan kiranya jika saksi itu diberikan perlindungan hukum, karena dalam kasus-kasus tertentu adakalanya saksi mendapat ancaman, gangguan, teror bahkan kekerasan yang dilakukan oleh pihak-pihak tertentu. Ancaman, gangguan, teror serta kekerasan tersebut dilakukan tidak lain adalah untuk menghalang-halangi

\footnotetext{
${ }^{1}$ M. Yahya Harahap, Pembahasan, Permasalahan dan Peenerapan KUHAP (Pemeriksaan Sidang Pengadilan, Banding, Kasasi, dan Penunjauan Kembali), Cetakan IVm Sinar Grafika, Jakarta, 2002, hlm. 286.

${ }^{2}$ Ibid.
} 
atau mencegah saksi untuk memberikan kesaksian atau keterangan yang sebenarbenarnya pada tingkat penyelidikan, penyidikan dan penuntutan serta pemeriksaan di depan sidang pengadilan. Hal inilah yang menjadi salah satu pertimbangan dikeluarkannya Undang-Undang No.13 Tahun 2006 tentang Perlindungan Saksi dan Korban sebagaimana telah diubah dan ditambah dengan Undang-Undang No.31 Tahun 2014 tentang Perubahan Atas Undang-Undang No.13 Tahun 2006 tentang Perlindungan Saksi dan Korban.

Di samping itu perlindungan saksi juga diatur dalam beberapa tindak pidana di Indonesia, seperti tindak pidana narkotika, tindak pidana korupsi, tindak pidana terorisme dan pengadilan Hak Asasi Manusia (HAM). Dengan demikian maka masalahnya dapat dirumuskan sebagai berikut:

1. Bagaimanakah bentuk perlindungan saksi dalam beberapa tindak pidana di Indonesia?

2. Bagaimanakah bentuk dan pentingnya perlindungan saksi dalam pengadilan HAM?

\section{Metode}

Jenis penelitian ini termasuk dalam kategori penelitian yuridis normatif yaitu suatu penelitian yang mengkaji permasalahan mengenai perlindungan saksi dalam beberapa tindak pidana dan peradilan hak asasi manusia dengan menggunakan pendekatan yang dilakukan berdasarkan bahan-bahan kepustakaan. Dalam hal ini dengan menelaah bahan hukum utama yang mengandung teori, konsep, asas hukum dan peraturan perundang-undangan yang berlaku yang berhubungan dengan permasalahan yang diteliti. Bahan hukum yang digunakan untuk mengkaji permasalahan dari penelitian ini adalah bahan hukum primer, bahan hukum sekunder dan bahan hukum tersier. Bahan-bahan hukum tersebut dianalisis secara kualitatif untuk mendapatkan hasil yang dapat memberikan jawaban dari permasalahan penelitian ini yang natinya hasil penelitian ini dapat dipertanggungjawabkan secara akademis.

\section{Hasil Dan Pembahasan}

\section{Perlindungan Saksi Dalam Beberapa Tindak Pidana}

Sebagaimana diketahui bahwa Hukum Acara Pidana Indonesia (KUHAP) tidak mengenal adanya perlindungan saksi dalam suatu proses perkara pidana. Menurut Soedjono Dirdjosisworo bahwa "tidak diaturnya masalah perlindungan saksi dan korban di dalam KUHAP merupakan suatu hal-yang sangat disayangkan". ${ }^{3}$

${ }^{3}$ Soedjono Dirdjosisworo, Pengadilan Hak Asasi Manusia Indonesia, PT Citra Aditya Bakti, Bandung, 2002, hlm. 91. 
Ternyata memang KUHAP tidak mengatur masalah perlindungan saksi dalam perkara pidana, akan tetapi hal tersebut terdapat dalam beberapa peraturan perundang-undangan terutama sekali dalam kejahatan-kejahatan berat. Hal ini dikarenakan kejahatan-kejahatan berat saksi perlu mendapatkan perlindungan hukum. Adapun peraturan perundang-undangan yang dimaksud antara lain:

a. Undang-Undang No.35 Tahun 2009 tentang Narkotika

Sebenarnya Undang-Undang No. 35 Tahun 2009 dibentuk dengan tujuan "untuk mewujudkan masyarakat Indonesia yang sejahtera, adil dan makmur yang merata materiil dan spiritual berdasarkan Pancasila dan Undang-Undang Dasar Negara Republik Indonesia Tahun 1945, kualitas sumber daya manusia Indonesia sebagai salah satu modal pembangunan nasional yang perlu dipelihara dan ditingkatkan secara terus menerus, termasuk derajat kesehatannya". ${ }^{4}$

Oleh karena itu Pasal 104 Undang-Undang No. 35 Tahun 2009 memberikan kesempatan kepada masyarakat yang seluas-luasnya untuk ikut serta membantu pencegahan dan pemberantasan penyalah-gunaan dan peredaran gelap narkotika dan Prekursor Narkotika. Kemudian dalam Pasal 105 Undang-Undang No.35 Tahun 2009 dinyatakan bahwa masyarakat juga mempunyai hak dan tanggung jawab dalam upaya pencegahan dan pemberantasan penyalahgunaan dan peredaran gelap Narkotika dan Prekursor Narkotika.

Selanjutnya Pasal 106 Undang-Undang No. 35 Tahun 2009 menambahkan bahwa bentuk hak masyarakat dalam upaya pencegahan dan pemberantasan penyalahgunaan dan peredaran gelap Narkotika dan Prekursor Narkotika, antara lain: (1) "Mencari, memperoleh, dan memberikan informasi adanya dugaan telah terjadi tindak pidana Narkotika dan Prekursor Narkotika", (2) "Memperoleh pelayanan dalam mencari, memperoleh, dan memberikan informasi tentang adanya dugaan terjadinya tindak pidana Narkotika dan Prekursor Narkotik kepada penegak hukum atau BNN", (3) "Menyampaikan saran dan pendapat secara bertanggung-jawab kepada penegak hukum atau BNN yang menangani perkara tindak pidana Narkotika dan Prekursor Narkotika”, (4) "Memperoleh jawaban atas pertanyaan tentang laporannya yang diberikan kepada penegak hukum atau BNN", (5) "Memperoleh perlindungan hukum pada saat yang bersangkutan melaksanakan haknya atau diminta hadi dalam prose peradilan".

Perlunya perlindungan hukum atau jaminan keamanan bagi saksi dalam tindak pidana narkotika, menurut Syaiful Bakhri, "karena penyalahgunaan dan peredaran gelap narkotika (kejahatan narkotika) pada umumnya tidak dilakukan oleh perorangan secara berdiri sendiri, melainkan dilakukan secara bersamasama dan melibatkan banyak orang, bahkan dilakukan oleh sindikat yang terorganisir dan memiliki jaringan yang luas dan melampaui batas-batas

\footnotetext{
${ }^{4}$ Bakhtiar, Kumulasi Pidana Penjara dan Denda Dalam Perkara Narkotika, Kanun Jurnal Ilmu Hukum, Vol. 21, No. 1, (April 2019), hlm. 33-34.
} 
negara". ${ }^{5}$ Di samping itu juga dalam Penjelasan Umum Undang-Undang No.35 Tahun 2009 dinyatakan bahwa "kejahatan narkotika terorganisir secara rapi, mantap, bahkan sangat rahasia, serta kejahatan narkotika bersifat transnasional dilakukan dengan menggunakan modus operandi dan teknologi canggih". ${ }^{6}$

Salah satu contoh diantara sekian banyak kejahatan narkotika yang terungkap adalah kasus penyeludupan narkotika yang terjadi pada Agustus 2020, yaitu "salah satu sindikat narkoba jaringan internasional yang mencoba menyelundupkan paket narkoba jenis ekstasi dari Belanda ke Indonesia. Empat pelaku yang ditangkap, salah satunya mantan anggota Polri yang sudah beberapa kali keluar masuk penjara". 7

Jika tidak adanya perlindungan atau jaminan keamanan bagi saksi dalam tindak pidana narkotika, tentunya saksi tersebut akan mendapat ancaman, gangguan ataupun teror dari pelaku, sindikat-sindikat atau jaringan tindak pidana narkotika tersebut. Para sindikat kejahatan narkotika tersebut tidak segan-segan menghabisi atau menghilangkan nyawa orang lain yang terkait dengan tindak pidana narkotika yang mereka lakukan. Salah satu contoh adalah "penemuan mayat seorang pria dalam kondisi bengkak di pantai di Desa Tanjung Karang, Kecamatan Sebatik Induk, Kabupaten Nunukan, Kalimantan Utara pada hari Rabu 29 Juli 2020. Diduga kuat, mayat tersebut adalah korban penganiayaan dan pembunuhan terkait jual beli narkoba". 8

Dengan demikian jelas bahwa pentingnya perlindungan hukum bagi saksi dalam tindak pidana narkotika, sehingga saksi mendapat jaminan keamanan terhadap dirinya sendiri dan juga keluarganya. Hal ini penting dalam pengungkapan atau membongkar tindak pidana narkotika, sehingga saksi merasa aman dan nyaman dalam memberikan keterangannya.

b. Undang-Undang No.31 Tahun 1999 tentang Pemberantasan Tindak Pidana Korupsi juncto Undang-Undang No.20 Tahun 2001

Menurut Gatot Supramono, "korupsi erat kaitannya dengan kekuasaan. Pelaku kejahatan korupsi biasanya orang-orang yang memegang jabatan penting. Jika diperhatikan para terpidana yang pernah diputus pengadilan karena melakukan tindak pidana korupsi selama ini, mereka dulunya pernah menduduki

\footnotetext{
${ }^{5}$ Syaiful Bakhri, Kejahatan Narkotika dan Psikotropika: Suatu Pendekatan Melalui Kebijakan Hukum Pidana, Gramata Publishing, Bekasi, 2012, hlm. 5.

${ }^{6}$ Penjelasan Umum Atas Undang-Undang No. 35 Tahun 2009 tentang Narkotika.

${ }^{7}$ https://news.detik.com/berita/d-5149038/polri-tangkap-sindikat-narkoba-jaringan-

internasional-satu-pelaku-eks-polisi, diakses 15 November 2020.

${ }^{8} \mathrm{https}$ ://nasional.kompas.com/read/2020/07/30/06070041/misteri-mayat-di-dalam-karungdiduga-korban-penganiayaan-sindikat-narkoba?page=all, diakses 15 November 2020.
} 
jabatan penting, baik di instansi pemerintah maupun swasta. Ada kepala bagian, kepala cabang, direktur sampai direktur utama".

Pada dasarnya semua orang tidak senang kalau perbuatannya yang tidak baik (apalagi suatu tindak pidana atau kejahatan) diketahui oleh orang lain, karena hak tersebut merupakan aib yang memalukan. Begitu juga halnya dengan kejahatan korupsi yang dilakukan oleh orang-orang yang pernah menduduki jabatan penting, maka ia akan sangat tidak senang dan marah jika perbuatannya itu menjadi pembicaraan orang, apalagi bawahan-bawahannya. Sehingga tidak jarang ia akan melakukan tindakan apa saja terhadap orang-orang yang melaporkan perbuatannya atau orang-orang yang membocorkan rahasianya.

Sehubungan dengan hal tersebut di atas, maka diperlukan adanya perlindungan hukum terhadap orang-orang yang melaporkan adanya tindak pidana korupsi (saksi pelapor). Dengan adanya perlindungan hukum tersebut diharapkan dapat terbongkarnya kejahatan korupsi. Dengan demikian siapa saja yang mengetahui adanya tindak pidana korupsi, maka ia tidak perlu takut untuk melaporkannya kepada pihak yang berwenang. ${ }^{10}$

Mengenai dengan perlindungan saksi dalam tindak pidana korupsi, Pasal 31 ayat (1) Undang-Undang No.31 Tahun 1999 disebutkan bahwa "saksi atau orang-orang yang berhubungan dengan tindak pidana korupsi dilarang menyebutkan identitasnya seperti nama, alamat pelopor, atau keteranganketerangan lain yang memungkinkan diketahuinya identitas mereka, baik di tingkat penyidikan maupun dalam pemeriksaan di pengadilan". Hal ini dimaksudkan supaya tidak diketahui siapa yang melapor adanya perbuatan korupsi tersebut, baik namanya maupun identitas lainnya. Di samping itu juga untuk mencegah kemungkinan adanya hal-hal yang dapat merugikan atau membahayakan keselamatan diri pelapor yang bersangkutan.

Dengan adanya ketentuan yang demikian, undang-undang sangat mengharapkan datangnya laporan-laporan tindak pidana korupsi dari masyarakat. Oleh karena itu, terhadap para pelapor perlu diberikan perlindungan yang sungguh-sungguh, untuk membantu usaha dalam pemberantasan tinda pidana korupsi.

c. Peraturan Pemerintah Pengganti Undang-Undang (Perpu) No.1 Tahun 2002 tentang Pemberantasan Tindak Pidana Terorisme juncto Undang-Undang No.15 Tahun 2003 dan Undang-Undang No.5 Tahun 2018

Perpu No.1 Tahun 2002 tentang Pemberantasan Tindak Pidana Terorisme melalui Undang-Undang No.15 Tahun 2003 telah ditetapkan menjadi undang-

\footnotetext{
${ }^{9}$ Gatot Supramono, Tindak Pidana Korupsi Di Bidang Perkreditan, Alumni, Bandung, 1977, hlm. 81-82.

${ }^{10}$ Ibid.
} 
undang, yang kemudian Undang-Undang No. 15 Tahun 2003 tersebut diubah dengan Undang-Undang No. 5 Tahun 2018, untuk selanjutnya disebut UndangUndang Pemberantasan Tindak Pidana Terorisme.

Pasal 33 ayat (1) Undang-Undang Pemberantasan Tindak Pidana Terorisme menyatakan bahwa: "Penyidik, penuntut umum, hakim, advokat, pelapor, ahli, saksi, dan petugas pemasyarakatan beserta keluarganya dalam perkara Tindak Pidana Terorisme wajib diberi pelindungan oleh negara dari kemungkinan ancaman yang membahayakan diri, jiwa, dan/atau hartanya, baik sebelum, selama, maupun sesudah proses pemeriksaan perkara".

Selanjutnya Pasal 34 Undang-Undang Pemberantasan Tindak Pidana Terorissme menyatakan bahwa: "Perlindungan yang diberikan kepada penyidik, penuntut umum, hakim dan petugas pemasyarakatan beserta keluarganya berupa perlindungan atas keamanan pribadi dari ancaman fisik dan mental, kerahasiaan identitas, dan bentuk pelindungan lain yang diajukan secara khusus oteh penyidik, penuntut umum, hakim, dan petugas pemasyarakatan". Pelindungan tersebut dilakukan oleh aparat penegak hukum dan aparat keamanan.

Pasal 34 Undang-Undang Pemberantasan Tindak Pidana Terorisme tersebut di atas merupakan "perlindungan yang diberikan kepada penyidik, penuntut umum, hakim dan petugas pemasyarakatan beserta keluarganya". Sedangkan perlindungan kepada pelapor, ahli, dan saksi beserta keluarganya diatur dalam Pasal 34 A Undang-Undang Pemberantasan Tindak Pidana Terorisme, yaitu: "Perlindungan atas keamanan pribadi dari ancaman fisik dan mental, kerahasiaan identitas, pada saat pemeriksaan di sidang pengadilan ketika memberikan keterangan tanpa-bertatap-muka dengan terdakwa. Pemeriksaan saksi dapat dilakukan secara jarak jauh (tanpa hadir di pengadilan) melalui audio visual".

Menurut Penjelasan Umum Atas Peraturan Pemerintah No.23 Tahun 2003 tentang Tata Cara Perlindungan Terhadap Saksi, Penyidik, Penuntut Umum dan Hakim Dalam Tindak Pidana Terorisme, dinyatakan bahwa "Pelindungan terhadap pelapor, ahli dan saksi serta keluarganya dilakukan oleh lembaga pelindungan saksi dan korban. Pemberian perlindungan terhadap saksi dalam tindak pidana terorisme tersebut sangat penting untuk menjamin kelancaran jalannya proses peradilan, sehingga dalam memberikan kesaksian, saksi merasa aman dari ancaman yang membahayakan diri, jiwa dan atau hartanya. Oleh karena itu dalam memberikan kesaksian, saksi harus merahasiakan identitasnya dan tidak bertatap muka dengan tersangka".

Menurut Fatwa Majelis Ulama Indonesia, "Terorisme merupakan kejahatan terhadap kemanusiaan dan peradaban serta merupakan salah satu ancaman serius terhadap kedaulatan negara Terorisme sudah merupakan 
kejahatan yang bersifat internasional yang menimbulkan bahaya terhadap keamanan, perdamaian dunia serta merugikan kesejahteraan masyarakat". ${ }^{11}$

Menurut Romli Atmasasmita, "terorisme telah menjadi pusat perhatian dunia internasional dan selalu menjadi topik pembicaraan utama hampir dalam setiap pertemuan, baik pertemuan bilateral, regional bahkan internasional. Hal ini dikarenakan terorisme telah menyentuh lingkaran peradaban manusia yang bersifat sangat immoral dan telah menghancurkan peradaban manusia, tidak mengenal atau membedakan sasaran yang menjadi korbannya, tidak membedakan jenis kelamin, usia, dan latar belakang agama, etnis serta ideologi. Korban kegiatan terorisme sudah multi agama, multi etnik, multi ideologi dan beragam usia. Kegiatan terorisme ini juga telah menimbulkan korban kerusakan fisik yang sangat parah dan menimbulkan kerugian yang tidak terhitung jumlahnya, termasuk tempat ibadah, bangunan sekolah dan fasilitas umum lainnya". ${ }^{12}$

Tindak pidana terorisme mulai marak pasca runtuhnya gedung World Trade Center (WTC) di New York. Dalam peristiwa tersebut, setidaknya korban tewas mencapai 6000 orang. Setahun kemudian, Indonesia merupakan negara yang menjadi sasaran para pelaku teror yang berpusat di Bali pada tahun 2002 yang mengakibatkan korban tewas di Paddy's Cafe dan Sari Club lebih dari 200 orang, dimana korban sebagian berasal dari warga negara asing. Berdasarkan kejadian pertahun, maka telah terjadi setidaknya lima serangan teror besar di Indonesia sejak tahun 2002, diantaranya teror Bom Bali I (2002), JW Marriot Hotel (2003), pengeboman Kedutaan Besar Australia (2004), Bom Bali II (2005), dan pemboman simultan di JW Marriot dan Ritz Carlton Hotel (2009)" ${ }^{13}$

Dengan demikian dilihat dari sifat tindak pidana terorisme yang tidak hanya dilakukan di suatu daerah, melainkan sudah melintasi kabupaten/kota, provinsi bahkan sudah lintas negara dan sudah bersifat internasional, yang dalam hal ini para pelakunya pun telah mempunyai jaringan yang luas dan telah terorganisir secara rapi, mantap, dan sangat rahasia. Hal inilah yang menjadi penyebab saksi merasa takut dan merasa terancam untuk memberikan keterangan yang sebenarnya terutama keterangan yang berkaitan dengan kejahatan terorisme. Inilah yang merupakan ancaman yang menakutkan bagi saksi dan keluarganya, Oleh karena itu jelas bahwa saksi beserta keluarganya dalam tindak

\footnotetext{
${ }^{11}$ Majelis Ulama Indonesia, Himpunan Fatwa Majelis Ulama Indonesia, MUI, Jakarta, 2010, hlm.725-726. juncto Terorisme merupakan kejahatan terhadap kemanusiaan dan peradaban https://ni.mil.id/view-115252-teroris-suatu-kejahatan-terhadap-negara.html, diakses 17 November 2020.

${ }^{12}$ Romli Atmasasmita, Aspek Nasional dan Global Pemberantasan Terorisme, Jurnal Hukum Internasional Vol. 2 No. 3, Bagian Hukum Internasional Fakultas Hukum UNPAD, Bandung, Desember 2003, hlm. 228.

${ }^{13}$ Bita Gadsia Spaltani, Peran Advokat Dalam Penegakan Hukum Terorisme Dengan Pendekatan Hukum Transedental, Kanun Jurnal Ilmu Hukum, Vol. 21, Nomor 3 (Desember, 2020), hlm. 399.
} 
pidana terorisme perlu diberikan perlindungan dari kemungkinan ancaman yang membahayakan diri, jiwa, keluarga, dan/atau hartanya, baik sebelum selama maupun sesudah proses pemeriksaan perkara tindak pidana terorisme.

\section{Perlindungan Saksi Dalam Pengadilan Hak Asasi Manusia}

Berkaitan dengan Hak Asasi Manusia (HAM) telah diatur dalam UndangUndang No.39 Tahun 1999 Tentang Hak Asasi Manusia. Undang-undang tersebut telah menentukan sejumlah norma yang berkaitan dengan HAM. Kemudian, dalam hal terjadinya pelanggaran HAM menurut Pasal 101 Undang-Undang No.39 Tahun 1999 bahwa : "Setiap orang, kelompok, organisasi politik, organisasi masyarakat, lembaga swadaya masyarakat, atau lembaga kemasyarakatan lainnya, berhak menyampaikan laporan tersebut kepada Komnas HAM atau lembaga lain yang berwenang dalam perlindungan, penegakkan dan pemajuan hak asasi manusia”.

Selanjutnya guna menjamin pelaksanaan hak asasi manusia serta memberi perlindungan, kepastian, keadilan, dan perasaana aman kepada setiap manusia atau masyarakat, telah dibentuk Pengadilan HAM untuk menyelesaikan pelanggaran HAM yang berat. Pengadilan tersebut dibentuk berdasarkan Undang-Undang No.26 Tahun 2000 tentang Pengadilan Hak Asasi Manusia yang mulai berlaku pada tanggal 23 November 2000. Dengan undang-undang ini diharapkan dapat melindungi HAM, dan menjadi dasar dalam penegakan hukum, kepastian hukum, keadilan, dan perasaan aman bagi perorangan dan masyarakat.

Berkaitan dengan perlindungan saksi dalam perkara pelanggaran hak asasi manusia, perlindungan saksi dalam perkara pelanggaran hak asasi manusia, Pasal 34 ayat (1) Undang-Undang No.26 Tahun 2000 menyatakan bahwa: "Setiap korban dan saksi dalam pelanggaran hak asasi manusia yang berat berhak atas perlindungan fisik dan mental dari ancaman, gangguan, teror, dan kekerasan dari pihak manapun". Kemudian dalam Pasal 34 ayat (2)-nya ditentukan bahwa: "Perlindungan sebagaimana dimaksudkan dalam ayat (1) wajib dilaksanakan oleh aparat penegak hukum dan aparat keamanan secara cuma-cuma".

Ketentuan mengenai tata cara perlindungan terhadap korban dan saksi, menurut Pasal 34 ayat (3) Undang-Undang No.26 Tahun 2000 akan diatur lebih lebih lanjut dengan Peraturan Pemerintah. Dalam hal ini peraturan pemerintah sebagaimana dimaksudkan dalam Pasal 34 ayat (3) Undang-Undang No.26 Tahun 2000 adalah Peraturan Pemerintah (PP) No.2 Tahun 2002 tentang Tata Cara Perlindungan Terhadap Korban dan Saksi Dalam Pelanggaran Hak Asasi Manusia Yang Berat.

Pasal 2 ayat (1) PP No.2 Tahun 2002 menentukan bahwa: "Setiap korban atau saksi dalam pelanggaran hak asasi manusia yang berat berhak memperoleh perlindungan dari aparat penegak hukum dan aparat keamanan". Kemudian dalam Pasal 2 ayat (2)-nya ditentukan bahwa: "Perlindungan oleh aparat penegak hukum dan aparat keamanan sebagaimana dimaksud dalam ayat (1) diberikan sejak tahap penyelidikan, penuntutan dan atau pemeriksaan di sidang pengadilan". 
Perlindungan saksi sebagaimana tersebut di atas dilakukan oleh aparat penegak hukum dan aparat keamanan berupa: "Perlindungan atas keamanan pribadi saksi dari ancaman fisik dan mental, kerahasiaan dan identitas saksi, pemberian keteranagan pada saat pemeriksaan di sidang pengadilan tanpa bertatap muka dengan tersangka" (Pasal 3 dan Pasal 4 PP No. 2 Tahun 2002).

Menurut Penjelasan Umum Atas PP No. 2 Tahun 2002 ditegaskan bahwa: "Dengan jaminan pemberian perlindungan tersebut diharapkan saksi dapat memberikan keterangan yang benar, sehingga proses peradilan terhadap pelanggaran hak asasi manusia yang berat dapat dilaksanakan dengan baik". Tanpa adanya perlindungan saksi, menurut Artidjo Alkostar bahwa "peradilan HAM akan tidak adil dan tidak independen". ${ }^{14}$ Hal ini penting, karena Pengadilan HAM Indonesia memiliki tanggung jawab moral dan tugas hukum untuk melaksanakan pengadilan yang adil dalam proses hukum. Dengan demikian Pengadilan HAM harus mengadopsi harga diri manusia, integritas nasional dan kepercayaan internasional.

Dengan demikian dapat dipahami bahwa perlindungan saksi dalam pengadilan HAM sangat penting, dalam rangka mewujudkan pengadilan HAM yang adil dan independen. Jika tidak adanya perlindungan terhadap saksi, maka mustahil pengadilan HAM itu akan adil dan independen. Apalagi di Indonesia, kebanyakan pelanggaran HAM dilakukan oleh para tersangka yang memiliki kekuasaan dan berpengaruh dalam birokrasi, termasuk pejabat tinggi militer. Sehingga militer, menurut Artidjo Alkostar menjadi salah satu variabel berpengaruh dalam proses penegakan hukum dan Pengadilan HAM. ${ }^{15}$

Berdasarkan uraian tersebut di atas jelaslah bahwa untuk mewujudkan pengadilan HAM yang adil dan indpenden, diperlukan adanya perlindungan terhadap saksi. Tanpa adanya perlindungan terhadap saksi, maka saksi tidak akan berani memberikan kesaksian ataupun memberikan kesaksian secara tidak benar, hal ini disebabkan karena adanya ancaman terhadap diri dan keluarga saksi, baik ancaman secara fisik maupun ancaman psikis.

\section{Penutup}

Peraturan perundang-undangan yang memberikan perlindungan terhadap saksi antara lain: Undang-Undang No.35 Tahun 2009 tentang Narkotika, UndangUndang No.31 Tahun 1999 tentang Pemberantasan Tindak Pidana Korupsi juncto Undang-Undang No. 20 Tahun 2001, Perpu No. 1 Tahun 2002 tentang Pemberantasan Tindak Pidana Terorisme juncto Undang-Undang No. 15 Tahun 2003 dan Undang-Undang No.5 Tahun 2018. Perlindungan saksi dalam tindak pidana tersebut pada umumnya untuk melindungi saksi dari ancaman yang

\footnotetext{
${ }^{14}$ Artidjo Alkostar, Pengadilan HAM, Indonesia dan Peradaban, PUSHAM-UII, Yokyakarta, 2004, hlm. 130.

${ }^{15}$ Ibid., hlm. 128-129.
} 
membahayakan keselamatan dirinya dan keluarganya. Sehingga saksi tidak diperbolehkan menyebutkan identitasnya atau keterangan lain yang memungkinkan diketahuinya identitas saksi, baik di tingkat penyidikan maupun dalam pemeriksaan di pengadilan.

Pentingnya perlindungan saksi dalam beberapa tindak pidana sebagaimana disebutkan dalam beberapa perundang-undangan di atas, karena tindak pidana tersebut bukanlah tindak pidana biasa melainkan tindak pidana yang modus operandinya sudah canggih dan luar biasa. Di samping itu juga tindak pidana tersebut tidak dilakukan secara sendirian, melainkan melibatkan banyak pihak bahkan melalui suatu jaringan yang melintasi daerah, kabupaten/kota, provinsi bahkan mancanegara, serta dapat melumpuhkan sendi-sendi kehidupan masyarakat. Akibatnya para saksi tidak leluasa bahkan tidak berani memberikan kesaksian ataupun memberikan kesaksian secara tidak benar. Apalagi saksi tersebut mendapat ancaman, teror dan sebagainya, baik terhadap diri dan keluarganya saksi, baik maupun terhadap harta benda miliknya.

\section{Daftar Pustaka}

\section{A. Buku}

Artidjo Alkostar, Pengadilan HAM, Indonesi dan Peradaaban, PUSHAM-UII, Yolyakarta, 2004.

Gatot Supramono, Tindak Pidana Korupsi di Bidang Perkreditan, Alumni, Bandung, 1977.

Lilik Mulyadi, Hukum Acara Pidana, PT Citra Aditya Bakti, Bandung, 1996.

Mien Rukmini, Perlindungan HAM Melalui Asas Praduga Tidak Bersalah dan Asas Persamaan Kedudukan Dalam Hukum Pada Sistem Peradilan Pidana Indonesia, Alumni, Bandung, 2003.

Soedjono Dirdjosisworo, Pengadilan Hak Asasi Manusia Indonesia, PT Citra Aditya Bakti, Bandung, 2002.

Wantjik Saleh., K., Tindak Pidana Korupsi, Ghalia Indonesia, Jakarta, 1977.

Wayan Parthiana, I., Hukum Pidana Internasional dan Ekstradisi, CV Yrama Widya, Bandung, 2004.

Yahaya Harahap, M., Pembahasan, Permasalahan dan Penerapan KUHAP (Pemeriksaan Sidang Pengadilan, Banding, Kasasi dan Peninjauan Kembali), Cetakan IV, Sinar Grafika, Jakarta, 2002. 


\section{B. Jurnal}

Bakhtiar, Kumulasi Pidana Penjara dan Denda Dalam Perkara Narkotika, Kanun Jurnal Ilmu Hukum, Vol. 21, No. 1, (April 2019).

Bita Gadsia Spaltani, Peran Advokat Dalam Penegakan Hukum Terorisme Dengan Pendekatan Hukum Transedental, Kanun Jurnal Ilmu Hukum, Vol. 21, Nomor 3 (Desember, 2020).

Romli Atmasasmita, Aspek Nasional dan Global Pemberantasan Terorisme, Jurnal Hukum Internasional Vo. 2 No. 3, Bagian Hukum Internasional Fakultas Hukum UNPAD, Bandung, Desember 2003.

\section{Internet}

https://news.detik.com/berita/d-5149038/polri-tangkap-sindikat-narkoba-jaringaninternasional-satu-pelaku-eks-polisi, diakses 15 November 2020.

https://nasional.kompas.com/read/2020/07/30/06070041/misteri-mayat-didalam-karung-diduga-korban-penganiayaan-sindikat-narkoba?page=all, diakses 15 November 2020.

https://tni.mil.id/view-115252-teroris-suatu-kejahatan-terhadapnegara.html, diakses 17 November 2020.

\section{Peraturan Perundang-Undangan}

Undang-Undang No. 8 Tahun 1981 tentang Hukum Acara Pidana.

Undang-Undang No.15 Tahun 2003 tentang Penetapan_Peraturan Pemerintah Pengganti Undang-Undang No. 1 Tahun 2002 tentang Pemberantasan Tindak Pidana Terorisme Menjadi Undang-Undang sebagaimana telah diubah dengan Undang-Undang No. 5 Tahun 2018 tentang Perubahan Atas Undang-Undang No. 15 Tahun 2003 tentang Penetapan Peraturan Pemerintah Pengganti Undang-Undang No. 1 Tahun 2002 tentang Pemberantasan Tindak Pidana Terorisme Menjadi Undang-Undang.

Undang-Undang No. 13 Tahun 2006 tentang Perlindungan Saksi dan Korban sebagaimana telah diubah dengan Undang-Undang No. 31 Tahun 2014 tentang Perubahan Atas Undang-Undang No. 13 Tahun 2006 tentang Perlindungan Saksi dan Korban.

Undang-Undang No. 35 Tahun 2009 tentang Narkotika.

Undang-Undang No.26 Tahun 2000 tentang Pengadilan Hak Asasi Manusia.

Undang-Undang No.31 Tahun 1999 tentang Pemberantasan_Tindak-Pidana Korupsi sebagaimana telah diubah dengan Undang-Undang No. 20 Tahun 2001 tentang Perubahan Atas Undang-Undang No. 31 Tahun 1999 tentang Pemberantasan Tindak Pidana Korupsi. 
Volume 15, Nomor 2, Juli-Desember 2020

Peraturan Pemerintah No. 2 Tahun 2002 tentang Tata Cara Perlindungan Terhadap Korban dan Saksi Daloam Pelanggaran Hal Asasi Manusia Yang Berat.

Peraturan Pemerintah No. 24 Tahun 2003 tentang Tata Cara Perlindungan Terhadap Saksi, Penyidik, Penuntut Umum dan Hakim Dalam Perkara Tindak Pidana Terorisme. 